\title{
THE ACQUISITION OF ENGLISH GRAMMAR MASTERY OF THE FIRST SEMESTER STUDENTS OF ENGLISH DEPARTMENT TEACHER TRAINING AND EDUCATION FACULTY OF MAHASARASWATI DENPASAR UNIVERSITY IN ACADEMIC YEAR 2009/2010.
}

\author{
Ni Made Wersi Murtini and I Nengah Astawa \\ English Education Department, Faculty of Education and Teacher Training, \\ University of Mahasaraswati Denpasar
}

\begin{abstract}
This study is focused on assessing the ability of the first semester students of English Department, Faculty of Teacher Training and Education of Mahasaraswati Denpasar University in academic year 2009/2010 in mastering English grammar. This study was intended to answer the Research Question: 'To what extent is the acquisition of English grammar mastery of the first semester students of English Department, the Faculty of Teacher Training and Education Mahasaraswati Denpasar University in academic year 2009/2010?. The data required were collected by administering the valid and reliable research instrument in form of multiple choice test. Then, the data were analyzed by using Norm Reference Measures of five standard values. The population of the study is the first semester students of English Department in the Faculty of Teacher Training and Education Mahasaraswati Denpasar University which consists of 120 students. They are considered to have heterogeneous characteristics. There were 30 students determined as the sample of the study using quota random sampling technique. The result of the data analysis showed that (1) $13.33 \%$ out of the whole subjects under study showed excellent ability in mastering grammar, (2) $6.66 \%$ showed good ability, (3) $53.33 \%$ showed sufficient ability, (4) $23.33 \%$ showed insufficient ability , (5) $3.33 \%$ showed poor ability in mastering grammar. If the result of the study were used as the bases to assign level to the subjects under study, then $26.66 \%$ fail in learning and acquiring English grammar. It means that $26.66 \%$ of them still have low ability. The finding of the present study was trusted to have rather limited degree of validity and reliability because it was conducted using an ex post facto research design and it has some inherent independent variables which contaminate the validity and reliability of the findings. The findings of the study can be used as the bases in planning better language teaching especially in mastering grammar.
\end{abstract}

Key Word : Acquisition, ex post facto, Norm Reference Measures

\section{INTRODUCTION}

In learning languages, mastering the grammar is very important according to the researcher's opinion. To be able to communicate the language properly, the learners should develop their grammar ability. Although the learners are good at reading and listening, but it is not guaranteed that they are good at grammar.

The most recognizable problem faced by the learner in learning English language as second language might be the mastery of grammar. Grammar is the rules in a language for 
changing the form of words and joining them into sentence (Hornby, 2005:675). English learners should be able to construct grammatical English sentences and utterances so that it is easier to understand by the listeners.

Grammar plays a very important rule in languages. Grammar affects the meaning of the sentences. Ungrammatical sentences will be nonsense and illogical which can be useless things to say. The problems of the English grammar faced by the students should be solved soon. Incorrect grammar is mostly caused and affected, in some cases, by their mother tongue.

The result of grammar teaching in senior high schools even in university particularly in Bali, are still remarked to be unsuccessful. To the writer's preobservation, the English grammar mastery of the first semester students of English Department the Faculty of Teacher Training and Education Mahasaraswati Denpasar University is still very low due to the lack of practicing English in their daily life and many students do not understand the function and the use of grammar, so that their grammar is very hard to be improved. Considering that grammar plays very important rules in a language regarding the communicative purposes in the students' daily life and future study, then the ability really needs to get serious attention.

Therefore, in accordance with the above facts, the researcher is highly motivated to measure the students' English grammar mastery based on the real analysis of the problems which are faced by both the classroom teachers and students. In this paper the researchers focuses their attention on tenses. As a matter of fact, the researchers' wish to provide valuable informative feedback trigger the undertaking of this investigation.

\section{Statement of Research Question}

Based on the background of the research above, the research question can be formulated as follows: to what extent is the acquisition of English grammar mastery of the first semester students of English Department of the Faculty of Teacher Training and Education Mahasaraswati Denpasar University in Academic Year 2009/2010?

\section{Objective of the Study}

The objective of the study is to find out the acquisition of English grammar mastery of the first semester students of English Department of the Faculty of Teacher Training and Education Mahasaraswati Denpasar University in Academic Year 2009/2010. 
The present study is based on the following related literatures: Second Language Acquisition; Conception of English Grammar; The Importance of Grammar . Further general description will be elaborated briefly below.

\section{Second Language Acquisition}

During the early 1970s a series of empirical investigations into learner language were carried out. These became known as the 'morpheme order' studies, and their principle aim was to find out whether there is a 'natural' sequence in the order in which second language learners acquire the grammar of the target language. The studies followed on from a pioneering piece of research by Brown in Nunan (1991:143), who discovered that children learning English as a first language passed through similar stages in acquiring fourteen grammatical structures and that, contrary to expectations, there was no relationship between the order in which items were acquired and the frequency with which they were used by the parents.

Dulay and Burt in Nunan (1991: 144) found that, like their first language counterparts, children acquiring a second language appeared to follow a predetermined order which could not be accounted for in terms of the frequency with which learners heard the language items. Moreover, children from very different first language backgrounds (Spanish and Chinese) acquired a number of morphemes in virtually the same order. However, the order differed from that of the first language learners investigated by Brown.Bailey et al in Nunan (1991: 144) replicated the studies with adult learners and came up with strikingly similar results.

As a result of these and other investigations, it was concluded that in neither child nor adult second language performance could the majority of errors be attributed to the learners' first language, that learners in fact made many errors in areas of grammar that are comparable in both the first and second language, errors which the contrastive hypothesis predicted would not occur. The researcher concluded from these investigations that a universal order of acquisition existed which was driven by an innate learning process. It is also appeared that the nature of the target language, rather than contrasts between the first and second language, drove the acquisition process.

\section{Conception of English Grammar}

Grammar is the rules in a language for changing the form of words and joining them into sentence (Hornby, 2005: 675). The word "grammar" has two meaning. One meaning of 
grammar is the way that we organize the sounds and signs of a language into something meaningful. In this sense of the term, we use grammar every time we say or write anything. We know how to organize the words (ice cream $)+($ want $)+($ an) into I want an ice cream, without having to think about it. There is another sense of the word of "grammar". It is the study and description of what is at work when we use language in an organized way. This kind of grammar does not come easily. Studying grammar is like studying a mechanic of walking (which is difficult), unlike the act of walking itself (which is easy) (Stern, 2002:01).

Jacobs and Rosenbaum (1968:267) state that grammar is something that we are well familiar with by the time we graduate from high school; indeed, a lot of time has been spent studying matters which are normally referred to as "grammar", which only very indirectly related to what have been studied in previous year.

If we are serious about learning a foreign language, we need to study grammar. Grammar can help us to learn a language more quickly and more efficiently. With the help of the grammar (or system) of a language, we can understand many things by ourselves, without having to ask a teacher or looking in the book.

Bowen and Madsen in Eliyanti (2004:12) cite that there are four ways in discussing the grammar of the written and oral language, they are (1) The grammatical tradition comes almost exclusively from the written language. (2) Grammar-translation and reading as the approved methods of the language teaching. (3) The records or classical language are in the written forms and almost exclusively concerned with written language. (4) Grammar of oral discourse is more easily derived from the grammar of written discourse and vice versa.

From the four sorts of grammar mentioned above it can be clearly grasped that the grammar of any languages is used both in written and oral forms. In oral form in communication there is a tendency to use much simpler grammar than in written forms. We talk more grammatical elements of English than we have to talk about the English Tenses.

\section{The Importance of Grammar}

Linguist defines grammar as a set of component; phonetics (the production and perception of sound), phonology (how sounds are combined), morphology (the study of forms or how elements are combined to create words), syntax (how words are strung together into sentences), and semantics (the study about meaning). All languages are characterized by these components, by definition, language does not exist without grammar. 
Grammar is a very important factor, so the English learner should learn English grammar. Without learning grammar, the learners of English will not be able to understand how to use English effectively such as speaking, writing, listening and reading. In using English effectively or good English, the user of English must understand good English grammar. Without grammar the listeners and readers will not understand what the speaker says.

Using the English grammar according to the conventions established by educated users of the language and adapting it to the circumstance in which we use it will not, of course, make us effective speakers and writers. According to Warriner in Eliyanti (2004:11) conventional usage is only one of the qualities of good speech and good writing.

Grammar is a system that puts words together into meaningful units (Morenberg, 1997:04). Grammar is the language that makes it possible for us to talk about language. Grammar names the types of words and word groups that make up sentences not only in English but in any languages. Most people, when they hear the word grammar, think of lots of useless, boring rules that they were forced to learn in school. As human beings, we can put sentences together even as children. But to be able to talk about how sentences are built, about the types of words and word groups that make up sentences that is said as knowing about grammar. And knowing about grammar offers a window into the human mind and into our amazing complex mental capacity.

People associate grammar with error and correctness, but knowing about grammar also helps us understand what makes sentences and paragraph clear, interesting and precise. And knowing about grammar means finding out that all languages and all dialects follow grammatical patterns.

\section{Significance of the Study}

One of the principle reflections which is taken into account in undertaking the present investigation is the significance of the expected research findings. The findings of the present study are expected to provide both theoretical and practical importance as follows:

1. Theoretically, the findings of the present study are to provide some evidence and to support the similar research that will be done in English Department the Faculty of Teacher Training and Education Mahasaraswati University Denpasar, particularly in the grammar mastery.

2. Practically, the findings of the present study are to provide some information to the teachers regarding the grammar acquisition and development of their students. 
Through the information of this study, the teacher will consider the better teaching technique in grammar in order to improve the students' grammar acquisition and to create an effective and efficient way of teaching and learning grammar.

3. The findings of the present study can be a motivation for the students to study the English grammar seriously. They might realize how important grammar is for a language to communicate in different contexts and purposes.

\section{RESEARCH METHOD}

It is mentioned previously that the present study deals with assessing the acquisition of English grammar mastery of the first semester students of English Department of the Faculty of Teacher Training and Education Mahasaraswati Denpasar University in academic year 2009/2010. The sample chosen for this study consisted of 30 students from the total population, that is 120 students all together. The students are the first semester students of English department of Teacher Training and Education Faculty of Mahasaraswati Denpasar University.

\section{FINDING AND DISCUSSION}

The result of the data analysis clearly showed that their mastery in grammar can be described below : (1) only 4 subjects (13.33\%) out of the whole subjects under study showed excellent ability in mastering grammar, (2) 2 subjects $(6.66 \%)$ out of the whole subjects under study showed good ability, (3) 16 subjects (53.33\%) out of the whole subjects under study showed sufficient ability, (4) only 7 subjects (23.33\%) out of the whole subjects under study showed insufficient ability, (5) and only 1 subject (3.33\%) out of the whole subjects under study showed poor ability. If the result of the study were used as the bases to assign level/grade to the subjects under study, it can be found that 8 students $(26.66 \%)$ out of 30 students fail in learning and acquiring English grammar. It means that $26.66 \%$ of them still have low ability.

The finding of the present investigation can therefore be remarked as unsatisfactory. It means that the skills of the first semester students of English Department of the Faculty of Teacher Training and Education of Mahasaraswati Denpasar University in academic year 2009/2010 in mastering grammar needs increasing. These findings can be used as informative feed back in planning much better teaching and learning process. In this case the students should be given more chance and exercises to be active in the teaching and learning process. 
They must be encouraged to be able to understand the use of grammar and able to apply it in their daily life

The discussions throughout the present investigation can finally be concluded as the following:

Firstly, The result of the data analysis using norm-reference measure of five standard values clearly shows that (1) 4 subjects $(13.33 \%)$ out of the whole subjects understudy showed excellent ability in mastering grammar, (2) 2 subjects (6.66\%) out of the whole subjects understudy showed good ability in mastering grammar, (3) 16 subjects (53.33\%) out of the whole subjects understudy showed sufficient ability in mastering grammar, (4) 7 subjects (23.33\%) out of the whole subjects understudy showed insufficient ability in mastering grammar, (5) 1 subject (3.33\%) out of the whole subjects understudy showed poor ability in mastering grammar. If the result of the study were used as the bases to assign level/grade to the subjects understudy, then there are 8 students (26.66\%) out of 30 students who fail in learning and acquiring English grammar.

The researcher fully realizes that there are inherently some factors which affect the ability of the students in mastering grammar which are simply beyond the control of the present study, such as the students' motivation in learning English. Their ability in English, their linguistic environment and also the qualification and the competence of the English teacher.

Secondly, The finding of the present study can be used as basis in planning much better communicative language teaching especially at teaching grammar at English Department the Faculty of Teacher Training and Education Mahasaraswati University Denpasar particularly in the future. By knowing the students' ability in constructing information in English the teachers can plan the next lessons in two ways that is (1) remedial for the insufficient and poor grade students, (2) improvement for those who get excellent, good and sufficient grade

\section{CONCLUSIONS}

The discussions throughout the present investigation can finally be concluded as the following:

From the result of investigation which was done at the first semester students of English Department of Teacher Training and education Faculty of Mahasraswati Denpasar university it can be said that the mastery of their grammar especially on tenses are still far from satisfactory. Since grammar is very very important for the students in order to be able to speak and write good English, so for them mastering grammar especially tenses is a must. 
Morepver in the future they are expected to be Englsih teacher after finishing their study in Higher college.

Since the research result shows as such, so the authority in the faculty might be able to make certain policy so that the quality of the students especially the English Department of Teacher Training and Education Faculty can be endlessly developed.

\section{Suggestions}

In reference to the findings of the present study then the researchers would like to suggest the following practical things:

The lecturers at English Department the Faculty of Teacher Training and Education Mahasaraswati University Denpasar are suggested to make better preparation in planning and teaching grammar as well as all skills in English such as reading, listening, speaking and writing. In this case the lecturers should give more attention to the use of tenses. The lecturers are suggested to be much more concerned at teaching grammar especially the use of simple tenses such as simple present tense, simple past tense and simple future tense, which are very important in speaking or daily conversation. The lecturers should teach how to construct affirmative sentences, negative sentences and interrogative sentences using those simple tenses. These tenses are used in guidance and free conversations, in interviews and reading comprehension.

The lecturers are recommended to be more active and creative in implementing and experimenting different technique of language teaching depending on the particular classroom situations. Learning atmosphere and conditions plays an important role, so it is expected that the attention and the motivation of the students in learning English can be increased especially for those who get insufficient and poor grade.

The Institution of the English Department should improve the curriculum so that it fits the standard educational system in order to make the teaching and learning process improve the students' ability. With a good curriculum of the institution implemented by qualified teachers, the knowledge taught might be easily understood by the students.

\section{REFERENCES}

Ary, Donald. 1979. An Introduction to Research in Education, New York : Hott, Rinehart and Winston.

Azar, Betty Schrampfer. 1993. Understanding and Using English Grammar, Jakarta : Binarupa Aksara.

Djiwandono, M. Soenardi. 1996. Tes Bahasa dalam Pengajaran. Bandung: Penerbit ITB. 
Jurnal Santiaji Pendidikan, 2010, 1(1): 76-84

Eliyanti, Ni Kadek. 2004. Teaching Grammar through Communicative Approach to the First Year Students of SLTP PGRI 1 Denpasar in Academic Year of 2003/2004. Unpublished Thesis.

Graver, B.D. 1963. Advanced English Practice. Oxford : Oxford University Press.

Hornby, A.S. 2005. Oxford Advanced Learner's Dictionary. Oxford. Oxford University Press.

Heaton, J.B. 1989, Writing English Language Test, A Practical Guide for Teachers of English as a Second Languge: Longman Group Ltd.

Jack, C. Richards. 1974. Error Analysis Perspective on Second Language Acquisition. London : Longman.

Jacobs, A. Roderick and Rosenbaum Peter S. 1968. English Transformational Grammar. Longman.

Kerlinger, N. F. 1977. Foundation of Behaviour Research. New York: Rinehart and Winston.

Krashen, Stephen D. 2009. Principles and Practice in Second Language Acquisition. University of Southern California.

Krohn, Robert. 1971. English Sentence Structure. USA : The University of Michigan Press.

Lado. 1988. Language Testing the Construction on Use of Foreign Language Tests. Longman.

Murphy, Raymond. 1994. English Grammar in Use, A reference and practice book for intermediate students. Cambridge : Cambridge University Press.

Morenberg, Max. 1997. Doing Grammar. New York : Oxford University Press.

Nunan, David. 1991. Language Teaching Methodology, A textbook for teachers, Sydney : Macquarie University.

Padmadewi N. and Ratminingsih M. 2003. Language Testing, A Module for English Department Students. Singaraja : IKIP Singaraja.

Quirk, Randolph. Greenbaum, Sidney. 1973. A University Grammar of English. London : Longman group ltd.

Ruku, Jorus. 2008. Assessing the Skills in Using the 'WH' Questions by the Second Year Students of Restaurant Program of SMK Pariwisata Harapan Denpasar in Academic Year 2007/2008. Unpublished thesis.

Stern, George. 2002. English Grammar. B \& Jo Enterprise Pte Ltd. Singapore 
Jurnal Santiaji Pendidikan, 2010, 1(1): 76-84 